\title{
LEADERIA:
}

JURNAL MANAJEMEN PENDIDIKAN ISLAM

Volume 1, Nomer 2, Desember 2020, Hal. 63-75

\section{LANDASAN TEOLOGIS MANAJEMEN PENDIDIKAN ISLAM}

\author{
Ahmad Jaelani $^{1}$, Nurwadjah Ahmad, E. $Q^{2}$, Andewi Suhartini ${ }^{3}$ \\ ${ }^{1}$ Universitas Garut \\ e-mail: ahmadjaelani1919@gmail.com \\ ${ }^{2}$ UIN Sunan Gunung Djati Bandung \\ e-mail: nurwadjah.ahmad@gmail.com \\ ${ }^{3}$ UIN Sunan Gunung Djati Bandung \\ e-mail: andewi.suhartini@uinsgd.ac.id
}

\begin{abstract}
The purpose of writing this article is to find out the management of Islamic education in theperspective of Islamic education theology. The writing of this article uses a qualitative approach with data sources obtained from literature studies or literature studies. The results of the writing of the paper obtained is that the management of Islamic education is not only about studying how to plan, organize, actualize and supervise, but all the processes carried out in management must be sourced from aspects of revelation that are manifested through beliefs and thoughts by not displaying the existence and intervention of God. Almighty.
\end{abstract}

Keywords: Theological, Islamic Education Management.

\begin{abstract}
ABSTRAK
Tujuan penulisan artikel ini adalah untuk mengetahui manajemen pendidikan Islam perspektif teologi pendidikan Islam.Penulisan artikel ini menggunakan pendekatan kualitatif dengan sumber data yang diperoleh dari kajian literature atau studi pustaka. Hasil penulisan makalah yang diperoleh adalah bahwasanaya manajemen pendidikan Islam bukan hanya mengkaji tentang bagaimana merencanakan, mengorganisasikan, mengaktualisasikan dan mengawasi saja, akan tetapi seluruh proses yang dilakukan dalam pengelolaah harus bersumber pada aspek kewahyuan yang dimanifestasikan melalui keyakinan dan pemikiran dengan tidak menapikan eksistensi dan intervensi Allah Yang Maha Kuasa.
\end{abstract}

Kata Kunci: Teologis, Manajemen Pendidikan Islam.

\section{PENDAHULUAN}

Pendidikan Islam merupakan sebuah konsep pendidikan yang berusaha menginternalisasikan nilai-nilai Islam bagi siapa saja yang berusaha mengkajinya guna mewujudkan seseorang agar memiliki kepribadian yang Islami serta mumpuni dalam keilmuan agama Islam (Tsaqafah) (Nafisah: 2012: 6). Secara dinamis, pendidikan Islam dipandang sebagai suatu pendidikan yang sangat penting, sehingga proses pelaksanaannya memerlukan pengelolaan 
yang baik agar esensi dari pendidikan tersebut dapat diimplementasikan dengan baik, dalam hal ini sudah tentu berkaitan dengan manajemen atau pengelolaan pendidikan itu sendiri.

Manajemen pendidikan Islam dewasa ini terus mendapatkan perhatian yang sangat serius. Ia tidak hanya berhubungan dengan konsep perencanaan, pengorganisasian, pengaktualisasian dan pengawasan dalam proses pendidikan saja, akan tetapi manajemen pendidikan Islam ini sangat berhubungan dengan aspek kewahyuan. Sehingga para ahli menyebutkan bahwa perbincangan mengenai pendidikan Islam tidak terlepas dari kajian mengenai al-Quran dan Sunnah.

Selain itu, manajemen pendidikan Islam memiliki peranan penting dalam pembentukan peradaban manusia dalam proses pendidikan. Khususnya peradaban manusia yang mumpuni dan berkepribadian Muslim. Nilai-nilai Islam pun kini telah merasuk ke berbagai disiplin ilmu, termasuk ilmu menajemen pendidikan. Hal yang menjadi dasar masuknya nilai-nilai Islam ke dalam manajemen pendidikan adalah Al-Qur'an dan hadits sebagai sumber pendidikan.

Tujuan dari manajemen pendidikan Islam yang bersumber pada aspek kewahyuan (AlQur'an dan Hadits) ini adalah agar proses pengelolan pendidikan Islam didasari keyakinan yang kokoh bahwasanya kewajiban manusia dalam proses pengelolaan pendidikan ini adalah hanya sebatas ikhtiar, selain itu menyadari akan derajat manusia yang Allah tinggikan melalui ilmu dan pendidikan. Berangkat dari hal inilah penulis mencoba mengkaji konsep manajemen pendidikan Islam perspektif teologi pendidikan Islam.

\section{METODE}

Pendekatan yang digunakan dalam penelitian ini adalah pendekatan kualitatif dengan menggunakan teknik pengumpulan data documenter, sedangkan teknik analisis datanya menggunakan analisis isi (content analysis).Jenis data yang digunakan yaitu berupa data sekunder.Penelitian dilakukan dengan mengidentifikasi permasalahan yang terjadi pada kegiatan pembelajaran disekolah, kemudian data dikumpulkan, dianalisis dan disimpulkan sesuai kebutuhan yang mungkin dapat menjadi penyelesaian masalah tersebut berupa strategi pengembangan dengan menggunakan studi kepustakaan.

\section{HASIL DAN PEMBAHASAN}

\section{A. Teologi Pendidikan Islam}

Pada saat bergejolaknya pendidikan barat, pendidikan Islam hadir sebagai sebuah alternatif sekaligus menjadi “ideologi” pendidikan berpresfektif Islam.Secara teologis, hal ini didasarkan pada sebuah pandangan otoritatif bahwa ajaran Islam datang dengan konsekuensi kebenaran jauh diambang batas filosofi pendidikan.

Pendidikan Barat yang berlandaskan pada asas sekularisme, menempatkan pemikiran dan eksistensi manusia pada maqam yang tinggi.Konsep pendidikan seperti ini sangatlah keliru, konsep 
ini berorientasi pada antropologis manusia, yakni memusatkan semuanya pada manusia (homo sentris), dan menafikan eksistensi dan intervensi Tuhan dalam kehidupannya.

Sekularisme yang dianut oleh pendidikan Barat telah menghancurkan tatanan pendidikan yang tidak sesuai dengan hakikat pendidikan.sehingga orientasi pendidikan pada pandangan barat berujung pada keresahan, kerisauan, dan kekeringan spiritual manusia.

Ajaran Islam sebagai dasar pengembangan pendidikan Islam menempatkan suatu kepercayaan dan keyakinan bahwa Allah memberikan pesan-Nya lewat al-Quran mempunyai tujuan untuk pencapaian kemaslahatan manusia.Allah telah memberikan pesan-Nya pada manusia dengan keterangan yang mujmal (universal), memberikan kesempatan pada manusia untuk memikirkannya secara tafsil (spesifik), tapi tetap tidak keluar dari konsekuensi teologis ke-Ilahian Allah Swt.

Istilah teologi sering dijumpai dalam wacana-wacana keagamaan.Istilah teologi ini identik dengan ilmu keyakinan, ilmu tauhid, dan ilmu akidah.Karena, teologi ini pada sebuah pemahaman dan corak pemikiran tertentu berisi mengenai ilmu-ilmu tersebut.Sebagian kelompok mengarahkan pengertian teologi ini pada ilmu kalam. Pemaparan mengenai istilah teologi atau kalam ini menurut penulis penting untuk diajukan untuk menegaskan apakah teologi pendidikan itu berhubungan dengan ilmu kalam yang mempunyai content pembahasan aliran-aliran kalam atau mutakallimin seperti yang dituangkan dalam referensi-referensi aliran tersebut.

Istilah teologi Islam diambil dari bahasa Inggris, theology.Reese mendefinisikannya dengan discourse of reason concerning God (wacana atau pemikiran tentang Tuhan). Dengan mengutip perkataan Ockham, Reese lebih jauh mengatakan: "Theology to be discipline resting on revealed truth and independent of both philosophy and science (teologi merupakan disiplin ilmu yang berbicara tentang kebenaran wahyu serta independensi filsafat dan ilmu pengetahuan). Selain pendapat Reese, Gove berpendapat bahwa teologi adalah penjelasan tentang keimanan, perbuatan, dan pengalaman keagamaan secara rasional (Rudi,2014:117).

Teologi secara sederhana menurut Komaruddin Hidayat dalam (Rudi, 2014:117) adalah ilmu atau penalaran kritis (logos) tentang Tuhan (teos). Teologi menurutnya muncul dari tradisi dan semangat beragama, sehingga didalamnya terkandung semangat iman dan pembenaran wahyu Tuhan.Teologi selalu dibedakan dari filsafat ketuhanan yang memberikan kebebasan pada nalar dalam membahas persoalan Tuhan tanpa harus terikat dengan wahyu.

Namun, dalam tradisi Islam, sebebas apa pun nalar berpikir, tetap ada penghormatan pada wibawa wahyu. Oleh sebab itu, tradisi filsafat Islam masih berdekatan dengan tradisi teologi.Yang membedakannya adalah dari segi metodologi.Filsafat lebih mengandalkan metode burhani (demonstratif) sedangkan teologi lebih bersifat jadali (dialektis).Yang pertama berangkat mencari kebenaran dengan membangun premis dan analisis secara kritis-radikal setapak demi 
setapak.Adapun yang kedua berangkat dari berbagai statement ayat atau wahyu yang kemudian saling dihadapkan dalam kerangka analisis untuk menangkan pesan Tuhan.

Komaruddin Hidayat dalam Rudi (2014:118) mengungkapkan bahwasannya teologi pendidikan secara sederhana bukan berarti konsepsi pendidikan yang diturunkan dari konsepsi pemikiran kalam, akan tetapi kajian konsepsi pendidikan yang diderivasikan dari penalaran kritis mengenai Tuhan (Teos) yang meliputi eksistensi dan "atribut" ketuhanannya. Penalaran kritis mengenai Tuhan ini tidak dapat dipisahkan dari memahami pesan-pesan Tuhan, termasuk di dalamnya pernyataan-pernyataan wahyu Tuhan.Konten pembahasan pada teologi pendidikan tidak dapat dipisahkan dari kajian mengenai pesan wahyu atau ayat juga interpretasinya.

Pendidikan merupakan sebuah upaya mengembangkan manusia ke arah kesempurnaan.Pendidikan juga merupakan upaya mengembangkan segala potensi manusia yang telah diberikan oleh-Nya menuju pada sesuatu yang diharapkan oleh-Nya. Pendidikan merupakan sebuah proses transformasi fitrah manusia yang asalnya baik, suci, mengantarkannya menjadi suci kembali, sesuai dengan kehendak-Nya sehingga ia diterima di sisi-Nya. Maka, kajian teologi pendidikan tidak serta merta berhubungan dengan Allah Swt, akan tetapi mengkaji pula tentang manusia yang sudah diciptakan dan diberikan berbagai potensi oleh Allah Swt.

\section{B. Manajemen Pendidikan Islam Perspektif Teologi Pendidikan Islam}

Berbicara mengenai pendidikan Islam tidak bisa dilepaskan dari sebuah pandangan bahwa Islam adalah sebuah agama. Sebagai sebuah agama, Islam mempunyai ajaran-ajaran yang berbeda secara mahiyah dengan konsepsi keagamaan yang lain. Ajaran Islam bersumber dari Allah melalui wahyu yang disampaikan kepada utusan-Nya yang terpilih, Muhammad Saw, Nabi yang dipilih-Nya ini menjadi representasi risalah kewahyuan. Muhammad Saw berbicara sesuai dengan masyiah pewahyuan "tidaklah ia berbicara sesuai dengan keinginannya melainkan menurut apa yang diwahyukan kepadanya.

Wahyu Allah tersebut kemudian termanifestasikan pada al-Quran sedangkan penjabaran dan interpretasi misi prophetik tertuang dalam sabda Nabi yang biasa dikenal dengan hadits. AlQuran dan hadits ini merupakan prime references bagi ajaran Islam.

Penjabaran dan eksplanasi mengenai kedua sumber ini dikembangkan oleh para ulama sesuai dengan misi prophetik dan perkembangan sosial yang berkembang baik pada zamannya maupun berupa prediksi-prediksi yang mungkin terjadi.Eksplanasi tersebut ada yang berkembang dengan sendirinya (al-fikrah al-istiqlaliyyah), demikian kata al-Dahlawi juga ada yang dikembangkan dengan konsensus bersama (ijma').

Pengembangan pemikiran keislaman yang bertaut antara teks dan konteks merupakan sebuah karya inovatif pada pemikir (mujtahid) dalam rangka mewujudkan kemaslahatan bersama, dengan kata lain mashlahat al-ammah. Para mujtahid mempunyai andil besar dalam rangka mengembangkan ajaran Islam dalam dimensi pemikiran, sekaligus menunjukkan aspek 
excellenceIslam pada sejumlah karya monumental yang membuat terperanjat umat dan bangsa lain. Islam mempunyai khazanah pemikiran yang luas dan mendalam pada berbagai disiplin ilmu.

Berkaitan dengan apa yang dikemukakan di atas, pendidikan Islam tidak bisa terlepas dari sumber-sumber tersebut. Pendidikan Islam berlandaskan pada sumber-sumber tersebut dan dikembangkan dengan memperhatikan konsepsi yang secara substantif terkandung pada sumbersumber tersebut.

Konsep manajemen pendidikan yang berlandaskan aspek kewahyuan (Al-Qur'an dan Hadits) akan menghasilkan manajemen yang bernilai lebih karena bukan sekedar dibangun diatas pemikiran logis-empiris, lebih dari itu manajemen pendidikan akan memiliki landasan religius dan keyakinan kepada Allah Swt.

Manajemen pendidikan berlandaskan Al-Qur'an dan Hadits berarti menempatkan AlQur'an dan Hadits sebagai acuan, hudan, sumber konsultasi dan sumber pendidikan. (Muhaimin,2010;10). Menempatkan Al-Qur'an dan Hadits dalam posisi yang demikian bukan berarti menafikan ilmu-ilmu kauniyah yang banyak ditemukan oleh manusia, namun justru mengintegrasikan dan mengkorelasikan antara Al-Qur'an dan hadits dengan ilmu-ilmu kauniyah yang ditemukan oleh manusia. Muhaimin menyebut ada 2 cara yaitu : deduksi dan induksi konsultasi (Muhaimin, 2010;16).

Cara deduksi dengan memulai mengkaji A-Qur'an dan Hadits, kemudian menafsirkannya. Dalam tahap ini akan memunculkan teori manajemen berbasis Al-Qur'an dan Hadits pada dataran filsafat, kemudian dieksperimenkan, dari sinilah akan muncul teori manajemen pendidikan berbasis Al-Qur'an dan Hadits. Kemudian diteorikan secara operasional yang akan menghasilkan petunjuk teknis (manual).

Sedangkan cara induksi konsultasi adalah dengan memulai mengkaji teori manajemen pendidikan yang sudah ada kemudian mengkonsultasikannnya dengan Al-Qur'an dan Hadits. Dalam proses mengkonsultsikan tersebut akan menghasilkan proses penguatan, penyempurnaan maupun pengkoreksian (Muhaimin,2010;16).

Ketika manajemen pendidikan dibangun di atas landasan Al-Qur'an dan Hadits, akan menghasilkan nilai lebih, di antaranya :

a. Proses perencanaan yang lebih futuristic. Perencanaan bukan hanya bersifat jangka pendek, menengah dan panjang yang kesemuanya dalam etape kehidupan di dunia saja , bahkan ada juga perencanaan jangka abadai yaitu mengkondisikan peserta didik supaya bisa menjadi penghuni surga. Kehidupan akhirat adalah kekal, tidak terbatas waktu, sehingga perlu diupayakan lebih sungguh-sungguh daripada sekedar mencapai kelayakan kehidupan di dunia yang hanya sekitar 70 tahun.

b. Proses organizing dan actuating yang ber-giroh kuat. Bagi seorang muslim, suatu perbuatan yang mendapat penguatan dan inspirasi dari AlQur'an dan Hadits membuat 
yang bersangkutan lebih semangat dalam menjalankannya karena memiliki nilai ibadah dan merasakan support dari Allah Swt. Dalam hal organizing bahkan dengan tegas Allah Swt menyebutkan bahwa diri-Nya sangat mencintai itu. Juga dalam hal actuating Allah Swt tidak menyukai orang-orang yang sekedar merencanakan tetapi tidak melaksanakannya.

c. Proses self control yang kuat. Dalam perspektif seorang muslim, control bukan hanya dilakukan oleh atasan, lembaga atau sistem tetapi juga diawasi oleh Allah Swt. Di sinilah potensi munculnya efisiensi dalam controlling, yaitu ketika atasan, lembaga atau sistem sedang tidak bisa mengontrolnya, seorang muslim tetap meyakini bahwa ada yang Maha Mengawasi yang selalu mengontrol dirinya.

\section{Landasan Toelogis Manajemen Pendidikan Islam}

Dasar landasan Teologis berkenaan dengan Manajemen Pendidikan Islam adalah AlQur'an.Salah satu fungsi Al-Qur'an adalah sebagai sumber petunjuk, termasuk petunjuk bagi manusia dalam rangka mengelola segala aktivitasnya terutama bidang pendidikan.

\section{Al-Qur'an dan Hadits Tentang Fungsi Manajemen}

Di atas telah dibahas tentang beberapa fungsi manajemen yaitu; planning, organizing, actuating dan controlling. Untuk keempat hal ini, terdapat inspirasi dalam Al - Qur'an sebagai berikut :

\section{a. Planning}

Planning adalah penentuan serangkaian tindakan untuk mencapai hasil yang diinginkan (Saefullah, 2012;22). Dalam Al Qur'an ditemukan ayat sebagai berikut :

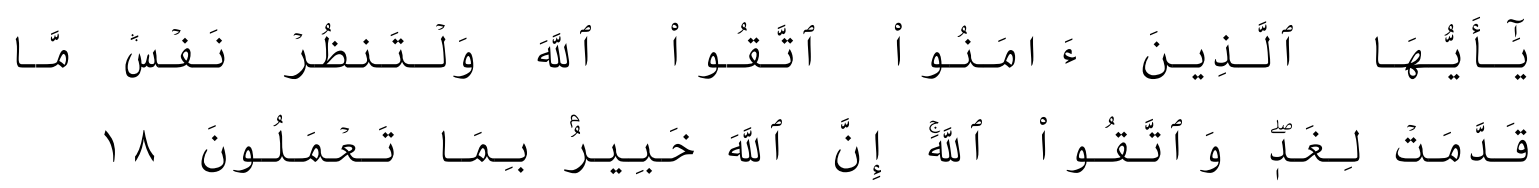

"Hai orang-orang yang beriman, bertakwalah kepada Allah Swt dan hendaklah setiap diri memperhatikan apa yang telah dibuatnya untuk hari esok, dan bertakwalah kepada Allah Swt, sungguh Allah Swt mengetahui apa yang kamu kerjakan”. (QS. Al-Hasyr/59;18.

Dalam ayat tersebut, ada isyarat bahwa perencanaan harus melibatkan pengalaman pengalaman masa lalu, yang dalam proses pendidikan di antaranya adalah potensi - potensi yang ada dalam diri pendidik maupun peserta didik.

Dari segi jangka waktunya, perencanaan ada yang berupa jangka pendek, menengah dan panjang. Ketiga perencanaan tersebut dibuat dalam cakupan kehidupan dunia yang itu juga dibolehkan Allah Swt yang kesemuanya merupakan proses awal untuk menuju kehidupan yang abadi yaitu kehidupan di kampung akhirat. Untuk itulah rencanaan jangka pendek harus menunjang pencapaian rencanaan jangka menengah.Rencana jangka menengah harus menuju tercapainya 
rencana jangka panjang dan rencana jangka panjang harus dalam upaya mencapai tujuan rencana jangka abadi.

Perintah untuk mengutamakan jangka abadi ini seperti Firman Allah Swt :

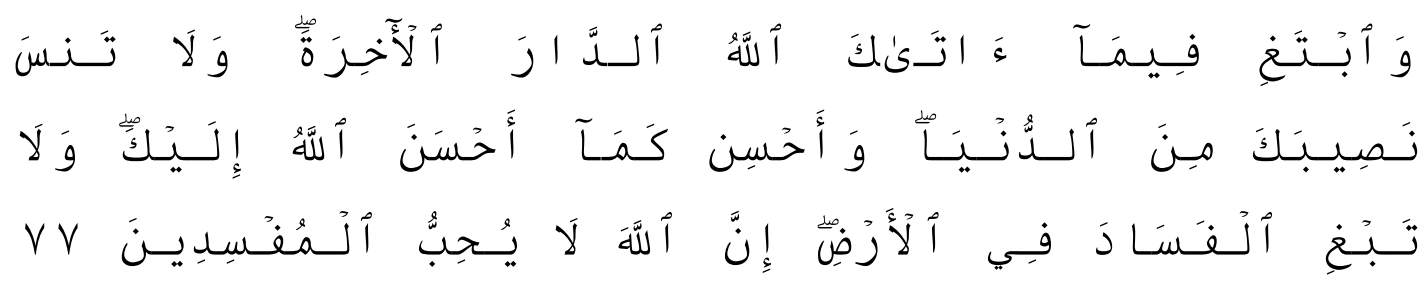

"Dan carilah apa yang dianugerahkan Allah Swt kepadamu, yaitu negeri akhirat dan janganlah kamu melupakan bagianmu dari (kenikmatan) duniawi”. (QS. AlQoshosh/28;77).

Ayat di atas menjelaskan bahwa dalam hal merencanakan sesuatu, kita harus meilih waktu dengan mempertimbangkan kemanfaatan yang panjang serta tujuan yang haqiqi, bukan hanya sebatas tujua duniawi saja, akan tetapi untuk kehidupan kelak di akhirat yang kekal dan abadi.

b. Organizing

Organizing adalah kerja sama antara dua orang atau lebih dalam cara yang terstruktur untuk mencapai sasaran spesifik atau sejumlah sasaran (Saefullah, 2012;22). Kata kunci dalam pengertian ini adalah kerjasama yang terstruktur. Dalam Al-Qur'an terdapat ayat berikut:

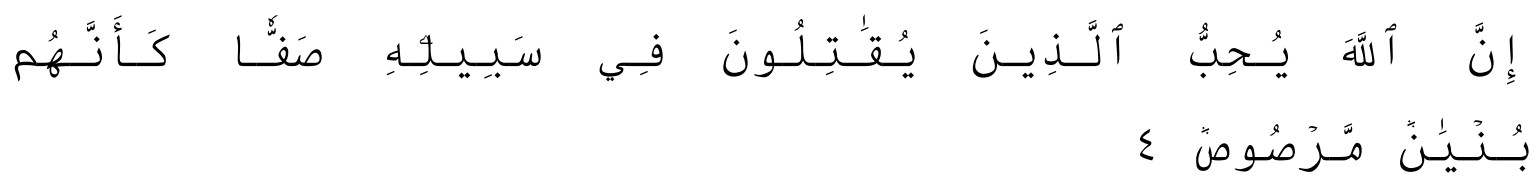

"Sungguh Allah Swt menyukai orang-orang yang berjihad di jalan-Nya dalam barisan yang teratur seakan-akan mereka seperti suatu bangunan yang tersusun kokoh" (QS. AshShoff/61;4).

Perencanaan yang baik perlu ditindaklanjuti dengan pengorganisasian yang baik.Pada ayat ini Allah Swt memberikan gambaran yang sangat memudahkan kita untuk memahaminya yaitu bangunan yang kokoh.Pemilihan diksi ini memberikan inspirasi; keterkaitan antar komponen, kokoh, saling menguatkan, teratur yang itu semua sangat dibutuhkan untuk terwujudnya pengorganisasian yang baik.

\section{c. Actuating}

Actuating adalah keseluruhan usaha, tehnik dan metode untuk mendorong para anggota organisasi agar mau dan ikhlas bekerja dengan sebaik mungkin demi tercapainya tujuan organisasi dengan efektif, efisien dan ekonomis (Hasibuan, 2008;25).

Planning dan organizing tidak akan menghasilkan apa-apa bila tidak ditindak lanjuti dengan eksekusi, pelaksanaan atau penerapan. Sikap seperti ini sangat tidak disukai Allah Swt sebagaimana firmanNya : 


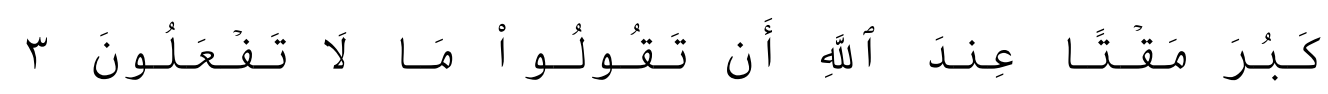

“Amat besar kebencian di sisi Allah Swt bahwa kamu mengatakan apa-apa yang tiada kamu kerjakan "(QS.Ash-Shoff/61;3)

Perencanaan dan pengorganisasian hanya akan menjadi sia-sia bila tidak dilanjuti dengan pelaksanaan, bahkan Allah Swt memilih diksi "kaburo maqtan" untuk kasus seperti ini. Artinya hanya kesombongan semata orang yang hanya bias merencanakan namun tidak ada pengaplikasian dari apa yang telah direncanakannya.

\section{d. Controlling}

Controlling adalah penilaian dan pengawasan terhadap segala hal yang dilakukan anggota organisasi sehingga dapat diarahkan ke jalan yang benar sesuai tujuan ( Saefullah, 2012;38).

Kisah Nabi Sulaiman yang termuat dalam Al-Qur'an memberikan inspirasi akan pentingnya controlling ini. Saat mendengarkan laporan dari salah satu anak buahnya, beliau lalu mengucapkan :

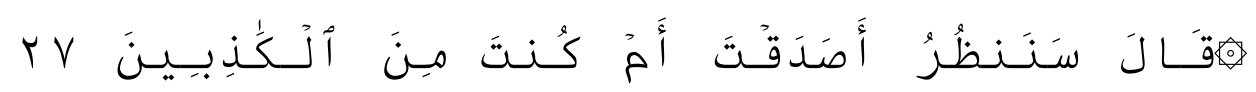

"Berkata (Sulaiman), "Akan kami lihat, apa kamu benar ataukah kamu termasuk orangorang yang dusta". (QS.An-Naml/27;27).

Bahkan pengawasan bukan hanya dilakukan oleh manusia, tetapi juga oleh malaikat, sebagaimana ayat berikut :

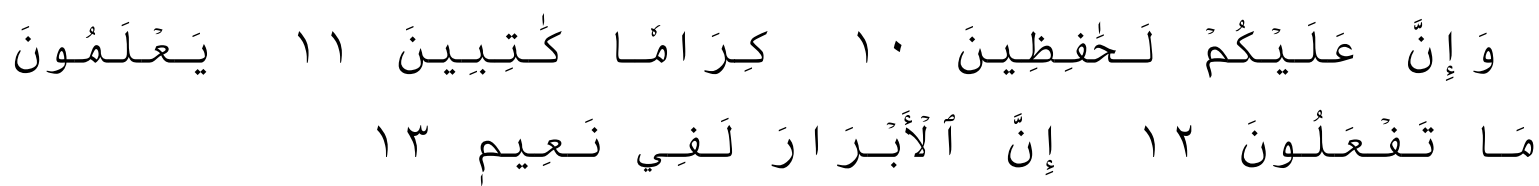

"Dan sungguh bagi kamu ada (malaikat-malaikat) yang mengawasi (pekerjaanmu), yang mulia dan yang mencatat, mereka mengetahui apa yang kamu kerjakan". (QS.AlInfithor/82;10-13).

Allah Swt menugaskan para malaikat untuk mengawasi manusia dan mencatat apa saja yang dilakukan oleh manusia. Ini memberikan inspirasi bahwa pengawasan itu penting, perlu didukung data yang valid, dan tidak harus dilakukan sendiri oleh atasan tetapi bisa melibatkan unsur lain baik internal maupun external seperti lembaga penjamin mutu, exterdal auditor dsb.

\section{2) Al-Qur'an dan Hadits tentang Prinsip-Prinsip Manajemen Pendidikan}

Dalam manajemen terdapat prinsip - prinsip yang merupakan pedoman umum atau pegangan utama pelaksanaan aktivitas manajerial, yang menentukan kesuksesan pengelolaan organisasi (Sefullah, 2012;10).

Berikut ditemukan beberapa ayat Al-Qur'an dan Hadits yang memberikan inspirasi tentang prinsip-prinsip manajemen:

a. Menjalankan Amanah 
Peserta didik adalah amanah yang telah diberikan kepada para pendidik. Melaksanakan amanah adalah kewajiban sebagaimana firman Allah Swt :

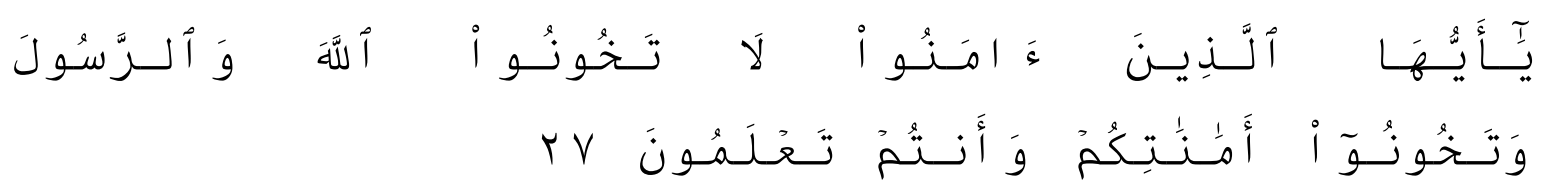

"Hai orang-orang yang beriman janganlah kamu mengkhianati Allah Swt dan Rosul dan janganlah kamu mengkhianati amanah-amanah yang dipercayakan kepadamu, padahal kamu mengetahui”. (QS.Al-Anfal/8;27).

Ayat di atas menegaskan kepada kita, bahwa menjaga amanah adalah salah satu perintah dari Allah Swt. Termasuk membimbing peserta didik. Peserta didik merupakan amanah langsung dari Allah Swt yang harus dijaga. Mereka harus dimuliakan karena mereka merupakan tamu Allah yang mulia sebagai generasi penerus bangsa yang eken membawa pada perubahan yang lebih baik.

b. Inovatif

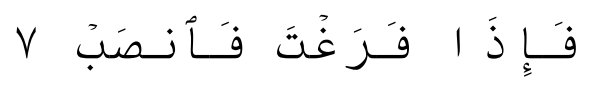

“Apabila kamu telah selesai mengerjakan suatu urusan maka segera kerjakan dengan sungguh-sungguh urrusan yang lain”.(Qs.Al-Insyiroh/94;7)

Inspirasi dari ayat tersebut adalah bila telah mencapai suatu target hendaklah segera dibuat target baru begitu secara terus menerus. Juga memberikan inspirasi supaya tidak puas diri dengan prestasi yang ada, tetapi terus berinovasi.

c. Efisien

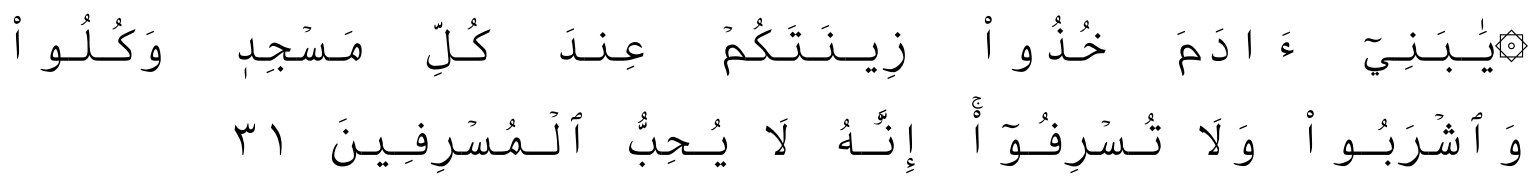

"Hai anak Adam, pakailah pakaianmu yang indah setiap memasuki masjid, makan dan minumlah dan janganlah berlebih-lebihan.Sungguh Allah Swt tidak menyukai orang-orang yang berlebih-lebihan”. (QS.Al-A'rof/7;31).

Dalam hal baju dan makanan saja Allah Swt memberikan petunjuk dengan jelas. Apalagi dalam hal pengelolaan manajemen yang jauh lebih banyak penggunaan anggarannya dituntut seefisien mungkin karena bila tidak diperhatikan akan banyak biaya pengadaan sarana dan pembiayaan kegiatan yang terbuang dengan percuma.

\section{d. Berkesinambungan (Continue)}

Prinsip berkesinambungan (Cintinue) sangat dibutuhkan dalam manajemen pendidikan untuk memastikan program atau kebijakan yang positif terus mendatangkan manfaat dan bisa mencapai targetnya. Sifat cepat bosan yang banyak menghinggapi dunia pendidikan menyebabkan program-program positif yang terbengkalai di tengah jalan. 


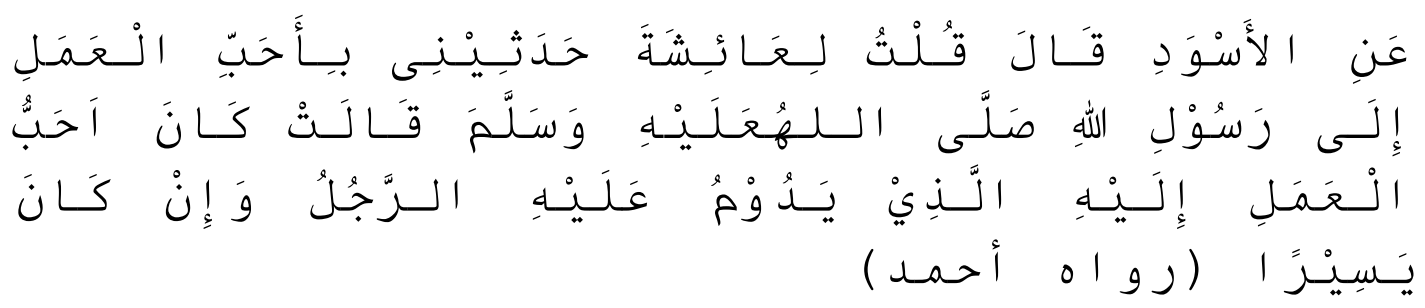

"Al-Aswad berkata "Saya berkata kepada Aisyah, "tolong ceritakan kepadaku amalan yang paling disukai oleh Rasulullah.Aisyah berkata, "Amalan yang paling beliau sukai adalah yang dilakukan oleh seseorang secara kontinyu walaupun amalan itu ringan”.. ( HR Ahmad No. 23675).

Sabda Rasul di atas menjelaskan bahwa amalan yang paling Allah sukai bukan hanya dilihat dari banyak dan beratnya saja, akan tetapi meskipun sdikit serta ringan, amalan tersebut dilakukan secara kontinyu serta istiqamah dalam mengamalkannya.

e. Pertanggungjawaban di akhirat secara individual

Interaksi antar anggota organisasi dalam kesatuan manajemen sangat diperlukan untuk menentukan tujuan, menerapkan program dan mempertanggung-jawabkannya. Di sinilah terjadinya pertarungan ide dalam perencanaan, tarik menarik antar kepentingan dalam pelaksanaan yang sangat mungkin terjadinya penyimpangan dari tujuan semula, bahkan tidak mungkin melanggar norma budaya dan aturan agama. Saat di akhiratpun akan dimintai pertanggungjawaban,namun bersifat individual, sebagaimana firman Allah Swt :

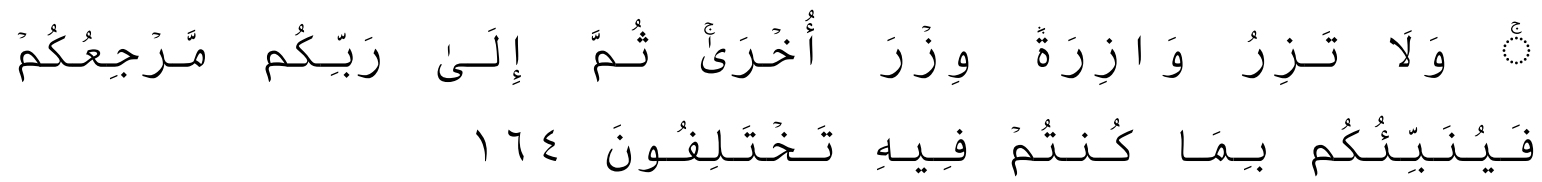

"Seseorang yang berdosa tidak akan memikul dosa orang lain. Kemudian kepada

Tuhanmu kamu kembali, dan akan diberitakanNya kepadamu tentang apa yang kamu perselisihkan”.(QS. Al-An'am/7;164).

Dalam hal amaliyah, seorang yang sudah mukallaf tentunya memiliki catatan amal masingmasing yang harus dipertanggung jawabkan. Pertanggung jawaban tersebut tentunya harus dipikul oleh dirinya sendiri tanpa melibatkan orang lain. Maka dari itu, seseorang dalam beramal hendaknya selalu waspada terhadap apa yang ia lakukan.

f. Pertanggungjawaban di dunia secara individual dan kolektif

Berbeda dengan di akhirat yang pertanggungjawabannya bersifat individual, di dunia ada pertanggungjawaban secara kolektif. Bila terjadi penyimpangan-penyimpangan dalam suatu lembaga pendidikan maka yang akan menerima akibatnya bukan hanya pelakunya tetapi seluruh komponen akan terkena juga dampaknya. Di sinilah pentingnya saling mengingatkan dan menguatkan untuk mentaati aturan yang ada. Hal seperti ini sebagaimana firman Allah Swt : 


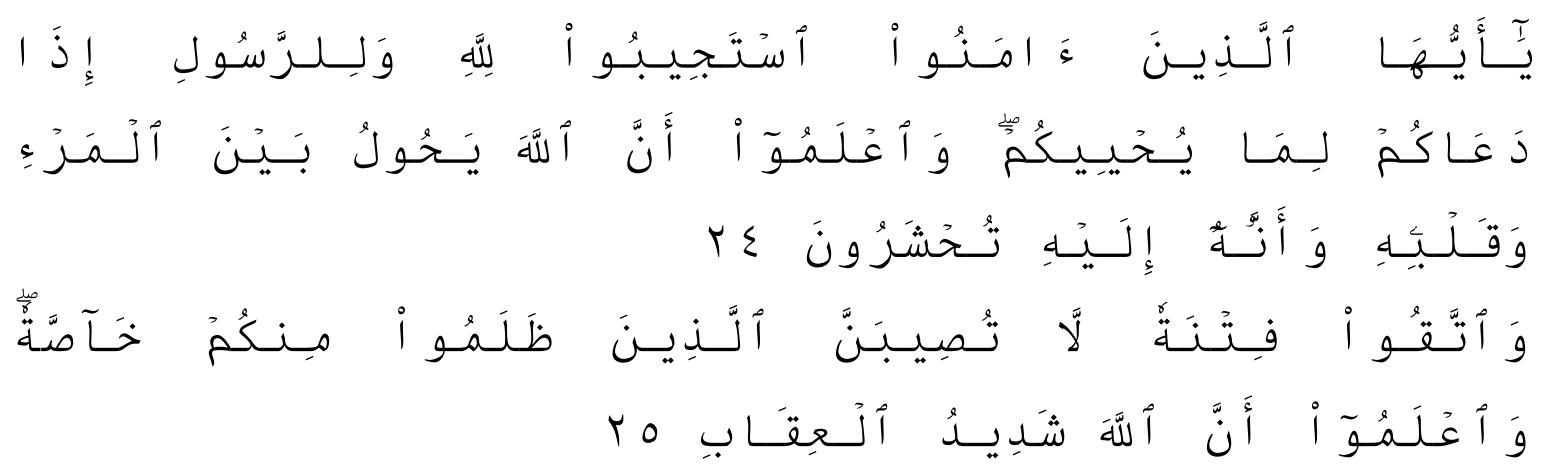

"Hai orang-orang yang beriman, penuhilah seruan Allah Swt dan seruan rosul apabila rosul menyeru kaтu kepada sesuatu yang memberi kehidupan kepadamu, dan ketahuilah bahwa sungguh Allah Swt membatasi antara manusia dengan hatinya dan sungguh kepadaNya lah kamu akan dikumpulkan. Dan peliharalah dirimu dari siksaan yang tidak khusus menimpa orang-orang yang dholim saja di antara kamu.Dan ketahuilah bahwa Allah Swt amat keras siksaan-Nya”. (QS.Al-Anfal/8;24-25).

Selain pertanggungjawaban secara individu, manusia yang tergolong makhluk sosial juga harus memperhtaikan hubungan muamalahnya dengan orang lain. Hhuungan manusia dengan yang lainnya (hablum minannaas) juga akan dipertanggung jawabkan, karena itu menyangkut haqqul adam kyang harus di islahkan.

\section{e. Al-Qur'an dan Hadits tentang Manajemen Kurikulum \& Kelas}

Manajemen kelas adalah serangkaian perilaku atau tindakan guru dalam upaya menciptakan dan memelihara kondisi kelas yang memungkinkan para murid mencapai tujuan tujuan belajarnya sec ara efisien (Antonio, 2011;62). Berikut disampaikan beberapa ayat Al-Qur'an dan Hadits yang memberikan inspirasi tentang manajemen kurikulum dan manajemen kelas.

a) Design kurikulum yang siap menghadapi globalisasi

"Tuntutlah ilmu walaupun sampai ke negeri Cina" (HR. Al-Baihaqiy no. 1612).

Perintah ini sangat futuristic disampaikan dahulu pada zaman Nabi.Perintah ini memberikan inspirasi dalam menghadapi globalisasi yang tidak mungkin dibendung pada saat ini.Tugas manajemen pendidikan adalah mendesign kurikulum yang bisa menyiapkan peserta didik dalam menghadapi globalisasi.

b) Design Kurikulum yang memperhatikan fisik dan ilmu

Saat bangsa Israel memprotes kepada salah satu nabinya yang telah menetapkan Thalut menjadi pemimpin bagi mereka dengan alasan bahwa Thalut hanya seorang petani dan perternak miskin dari desa, maka sang Nabi memberikan argument tentang kelebihan Thalut sebagai berikut : 


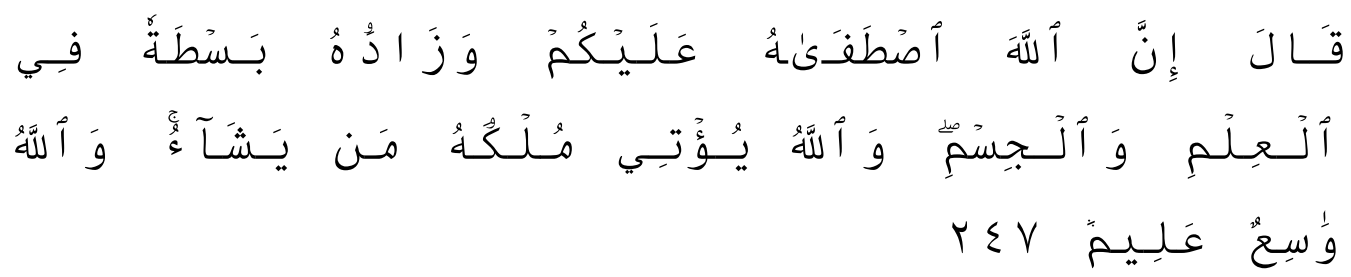

Nabi mereka berkata, “ Sungguh Allah Swt telah memilihnya menjadi rajamu dan menganugerahinya ilmu yang luas dan tubuh yang perkasa" (QS.Al-Baqoroh/2; 247).

Dari kisah ini terdapat inspirasi bahwa untuk menghasilkan output pendidikan yang memiliki daya saing global maka peserta didik harus disiapkan menguasai ilmu dan memiliki fisik yang baik.

c) Penjajakan dan Pengelompokkan

Penjajakan merupakan langkah awal seorang guru untuk melihat kondisi obyektif kemampuan murid.Penjajakan ini sangat penting untuk memudahkan guru dalam menyusun rencana pembelajaran yang mencakup materi dan metode. Rasulullah memberi contoh dengan sabda Beliau :

"Kami para nabi diperintahkan untuk memosisikan manusia sesuai dengan posisinya masing-masing dan menjelaskan mereka sesuai dengan tingkat akal mereka”.

Pengelompokkan merupakan salah satu strategi para Nabi dalam menyelesaikan urusan tertentu, maka dari itu sepatutnya kita mengikuti apa yang dicontohkan para Nabi untuk umatNya demi mencapai sebuah kemaslahatan bersama.

d) Penggunaan Multimedia

"Rasulullah pernah membuat garis seperti bujur sangkar, lalu membuat garis di bagian tengah hingga keluar bujur sangkar tersebut.Kemudian beliau membuat garis - garis kecil menuju garis tengah dari salah satu sisi garis tengah tersebut.Beliau kemudian berkata "Ini adalah manusia.Ini ajalnya yang mengitari dirinya.Ini adalah orang yang keluar dari cita citanya, sedangkan garis kecil ini adalah rintangan rintangan. Jika ia sudah melangkah di sini, garis ini akan memotongnya. Jika ia melakukan kesalahan di sini, garis ini akan memotongnya”.(HR. Bukhori Hadits No. 6417, Jilid 7 hlm 220.

Penggunaan media, merupakan salah satu strategi yang dilakukan oleh Rasulullah dalam menyampaikan sebagian dakwahnya guna memberikan pemahaman kepada manusia tentang apa yang disampaikannya. Oleh karena itu, Rasul saja yang di Ma'shum dari kesalahan masih menggunakan media dalam menyampaikan dakwahnya, apalagi kita manusia yang tak luput dari kesalahan dan dosa, sudah barang tentu harus lebih mengupayakan bagaimana ajakannya bias tersampaikan dengan baik. 


\section{KESIMPULAN DAN SARAN}

Pada awal pembahasan, dijelaskan dengan cukup detail mengenai pendidikan Islam dan pendidikan barat.Pendidikan Barat terkesan tidak memiliki ruang konsepsi kehendak Tuhan, keridhaan Tuhan, konsepsi penghambaan manusia pada Tuhan, apalagi konsepsi tentang kehidupan pasca dunia (Akhirat).Pandangan Barat lebih mengena pada kepentingan manusia semata (humancentris) tanpa berusaha untuk mengaitkannya dengan intervensi Realitas Tertinggi (Kekuasaan Allah).Hal ini menyebabkan pendidikan mengantarkan manusia menjadi materalistik, hedonistik, pragmatis, dan terkadang jatuh pada lembah ateistik.Akibatnya eksistensi kejiwaan, credo, dan spiritual tidak terjamah sehingga manusia menjadi risau, resah, dan gelisah akibat pemujaan atas hasil pikir manusia.Pendidikan dalam sudut pandang Islam terutama yang ditopang oleh teologi seperti yang diungkapkan di atas, memberikan pencerahan bagi permasalahan pendidikan seperti itu. Islam bukan berarti tidak memandang secara optimal kemampuan manusia, namun dibalik semua itu ketercapaian kemajuan manusia sebagai hasil proses pendidikan tetap berada pada koridor relasi dan keterlibatan Tuhan. Pendidikan Islam dengan sudut pandang teologi menghadirkan sebuah alternatif sudut pandang pengembangan konsepsi pendidikan.

Pendidikan dalam persfektif teologi bercermin pada sebuah asumsi bahwa Tuhan mempunyai posisi superlatif jauh daripada posisi kekuasaan dan kebebasan manusia.Teologi ini mencoba untuk membuat sebuah konsepsi pendidikan yang sesuai dengan kehendak-Nya yang tertuang dalam wahyunya yakni, Al-Qur'an serta pesan-pesan lain-Nya.

Teologi pendidikan menjadi sebuah fondasi penting dalam pengembangan pendidikan Islam. Konsekuensi konsep dasar teologi jika disederhanakan menjadi : berawal dari Tuhan dan kembali pada kehendak Tuhan untuk kesejahteraan manusia. Sedangkan paradigma pendidikan lain menyatakan berawal dari manusia kembali untuk manusia, tanpa menapikan relasi dengan Tuhan.

\section{DAFTAR PUSTAKA}

\section{Buku:}

Hidayat, K. 2004. Menafsirkan Kehendak Tuhan.Bandung: Teraju.

Muhaimin dan Muzakkir, J. 2005. Kawasan dan Wawasan Islam. Jakarta: Prenada.

Rahmat, A. 2013. Manajemen Pendidikan Islam. Gorontalo: Ideas Publishing.

Saefullah. 2014. Manajemen Pendidikan Islam. Bandung: PT Pustaka setia.

Tafsir, A. 2014. Ilmu Pendidikan Dalam Pespektif Islam. Bandung: PT Remaja Rosdakarya.

\section{Jurnal :}

Suryadi, A.R. 2014. Mengusung Pendidikan Islam Perspektif Teologis.

Jurnal Pendidikan Agama Islam - Ta'lim.Vol. 12 No. 2.UPI. 
Kurniawan, S. 2015.Konsep Manajemen Pendidikan Islam Perspektif Teologi Pendidikan Islam. Jurnal Nur El-Islam, Volum 2 No. 2.Oktober 2015. 